\title{
ESTIMATING SUBSOIL RESISTANCE TO NITRATE LEACHING FROM EASILY MEASURABLE PEDOLOGICAL PROPERTIES $^{(1)}$
}

\author{
Fábio Keiti Nakagawa ${ }^{(2)}$, Gabriel Benjamin Siqueira Forti ${ }^{(2)}$, Marcelo Eduardo Alves $^{(3)}$, \\ Arquimedes Lavorenti \& Jarbas Honório de Miranda ${ }^{(4)}$
}

\begin{abstract}
SUMMARY
Leaching of nitrate $\left(\mathrm{NO}_{3}{ }^{-}\right)$can increase the ground water concentration of this anion and reduce the agronomical effectiveness of nitrogen fertilizers. The main soil property inversely related to $\mathrm{NO}_{3}$ - leaching is the anion exchange capacity (AEC), whose determination is however too time-consuming for being carried out in soil testing laboratories. For this reason, this study evaluated if more easily measurable soil properties could be used to estimate the resistance of subsoils to $\mathrm{NO}_{3}$ - leaching. Samples from the subsurface layer $(20-40 \mathrm{~cm})$ of 24 representative soils of São Paulo State were characterized for particle-size distribution and for chemical and electrochemical properties. The subsoil content of adsorbed $\mathrm{NO}_{3}{ }^{-}$was calculated from the difference between the $\mathrm{NO}_{3}{ }^{-}$contents extracted with $1 \mathrm{~mol} \mathrm{~L}^{-1} \mathrm{KCl}$ and with water; furthermore, $\mathrm{NO}_{3}{ }^{-}$ leaching was studied in miscible displacement experiments. The results of both adsorption and leaching experiments were consistent with the wellknown role exerted by AEC on the nitrate behavior in weathered soils. Multiple regression analysis indicated that in subsoils with (i) low values of remaining phosphorus (Prem), (ii) low soil $\mathrm{pH}$ values measured in water (pH $\mathrm{H}_{2} \mathrm{O}$ ), and (iii) high $\mathrm{pH}$ values measured in $1 \mathrm{moL} \mathrm{L}^{-1} \mathrm{KCl}(\mathrm{pH} \mathrm{KCl}$ ), the amounts of surface positive charges tend to be greater. For this reason, $\mathrm{NO}_{3}{ }^{-}$leaching tends to be slower in these subsoils, even under saturated flow condition.
\end{abstract}

Index terms: anion exchange capacity, remaining phosphorus, retardation factor.

\footnotetext{
(1) Received for publication in September 22, 2011 and approved in July 24, 2012.

(2) Agronomy undergraduate student, Escola Superior de Agricultura "Luiz de Queiroz" - ESALQ/USP. Av. Pádua Dias, 11. CEP 13418-900 Piracicaba (SP). E-mail: fabiokeitinakagawa@yahoo.com.br; cm_gabol@hotmail.com

(3) Professor of Departamento de Ciências Exatas, ESALQ/USP. E-mail: mealves.esalq@usp.br; lavorenti@ usp.br

(4) Professor of Departamento de Engenharia de Biossistemas, ESALQ/USP. E-mail: jhmirand@usp.br
} 


\title{
RESUMO: ESTIMATIVA DA RESISTÊNCIA DE SUBSOLOS À LIXIVIAÇÃO DE NITRATO A PARTIR DE PROPRIEDADES PEDOLÓGICAS DE FÁCIL DETERMINAÇÃO
}

\begin{abstract}
A lixiviação de nitrato $\left(\mathrm{NO}_{3}^{-}\right)$pode aumentar a concentração desse ânion no lençol freático e reduzir a eficiência agronômica dos fertilizantes nitrogenados. A capacidade de troca aniônica (CTA) é a principal propriedade do solo inversamente relacionada à lixiviação de nitrato; todavia a morosidade associada à quantificação da CTA inviabiliza sua determinação em laboratórios dedicados à avaliação da fertilidade do solo. Por essa razão, a presente pesquisa foi conduzida com o objetivo de avaliar se atributos pedológicos mais facilmente determináveis poderiam ser utilizados para estimar resistência de subsolos à lixiviação de $\mathrm{NO}_{3}{ }^{-}$. Amostras coletadas na camada subsuperficial (20-40 cm) de 24 solos representativos do Estado de São Paulo foram caracterizadas quanto à granulometria e a alguns atributos químicos e eletroquímicos. O teor de $\mathrm{NO}_{3}{ }^{-}$adsorvido foi calculado a partir da diferença entre seus teores extraídos com solução de $\mathrm{KCl} 1 \mathrm{~mol} \mathrm{~L} \mathrm{~L}^{-1}$ e com água; adicionalmente, a lixiviação de $\mathrm{NO}_{3}^{-}$foi estudada por meio de experimentos de deslocamento miscivel. Os resultados foram concordantes com a conhecida importância da CTA tanto para a adsorção quanto para o retardamento da lixiviação de $\mathrm{NO}_{3}^{-}$em subsolos intemperizados. Por meio de análise de regressão linear múltipla foi possível observar que subsolos que apresentam (i) baixos valores de fósforo remanescente (Prem), (ii) baixos valores de $\mathrm{pH}$ determinados em água $\left(\mathrm{pH} \mathrm{H}_{2} \mathrm{O}\right)$ e (iii) altos valores de $\mathrm{pH}$ determinados em solução de $\mathrm{KCl} 1 \mathrm{~mol} \mathrm{~L}^{-1}$ ( $\mathrm{pH} \mathrm{KCl)} \mathrm{tendem} \mathrm{a} \mathrm{apresentar} \mathrm{quantidades} \mathrm{mais} \mathrm{elevadas} \mathrm{de} \mathrm{cargas}$ positivas. Por essa razão, a lixiviação de $\mathrm{NO}_{3}{ }^{-}$tende a ser mais lenta nesses subsolos mesmo sob condição de fluxo saturado.
\end{abstract}

Termos de indexação: capacidade de troca aniônica, fósforo remanescente, fator de retardamento.

\section{INTRODUCTION}

Nitrate $\left(\mathrm{NO}_{3}{ }^{-}\right)$is the most oxidized nitrogen form in non-flooded soils which can be taken up by plants or transported into subterranen aquifers after intense rainfall or irrigation. This leaching can increase $\mathrm{NO}_{3}-$ concentrations to $>10 \mathrm{mg} \mathrm{L}^{-1} \mathrm{~N}$ in the groundwater, making it unsuitable for drinking (Brasil, 2001). Although Addiscott \& Benjamin (2004) pointed out that there is no scientific evidence of nitrate-related damages to human health, the main concerns with regard to this anion are associated with its apparent involvement in the development of stomach cancer in adults and of methemoglobinemia in newborns (Addiscott, 2006).

Besides not giving rise to any insoluble products, nitrate, unlike anions such as sulfate and fluoride, occurs as non-complexed or "free" negatively charged ion $\left(\mathrm{NO}_{3}{ }^{-}\right)$in the soil solution. Therefore, the electrostatic adsorption by the surface positive charges of soil minerals plays an essential role in retarding $\mathrm{NO}_{3}{ }^{-}$leaching (Ji, 1997; Dynia \& Camargo, 1999; Alcântara \& Camargo, 2010; Harmand et al., 2010). However, along with the amount of soil positive surface charges, other factors such as aquifer depth, local rainfall, rate and frequency of $\mathrm{N}$ fertilization, $\mathrm{N}$ uptake efficiency of crops, irrigation management and soil properties (e.g., porosity, texture and mineralogy) must be taken into consideration to assess the risk of groundwater contamination by $\mathrm{NO}_{3}{ }^{-}$(Resende, 2002).
Liming and fertilization are essential for crops on tropical soils, but both practices favor $\mathrm{NO}_{3}{ }^{-}$leaching. Dynia \& Camargo (1999) verified that liming and phosphate fertilization reduced $\mathrm{NO}_{3}{ }^{-}$adsorption in the plowed layer of a Brazilian Ferralsol. Similarly, Alcântara \& Camargo (2010) observed that applications of carbonate, phosphate and sulfate favored $\mathrm{NO}_{3}{ }^{-}$leaching in an electropositive Ferrasol. The effect of liming to reduce $\mathrm{NO}_{3}$ - adsorption results from the increase in the net negative surface charge that occurs in variable charge soils after the $\mathrm{pH}$ rises; on the other hand, the depletion of $\mathrm{NO}_{3}$ - adsorption sites caused by the presence of other anions, e.g., phosphate and sulfate, can be ascribed to the greater preference of the positive surface charges for those anions than for $\mathrm{NO}_{3}$. Harmand et al. (2010) observed that the $\mathrm{NO}_{3}$ - adsorption by an Acrisol in Costa Rica was greater in deeper layers in agreement with the progressive increase in the net positive surface charge that was also observed from the soil surface to a depth of $180 \mathrm{~cm}$.

Although the soil content of clay-size particles is usually positively correlated with $\mathrm{NO}_{3}$ - adsorption, this straightforward relationship is not always observed due to mineralogical differences among soils. To evaluate the $\mathrm{NO}_{3}$ - fate in soil, it would therefore be useful to consider soil properties that are not only faster to measure but also consistently correlated with the soil mineralogical composition and with its amount of positive surface charges. In this context, a potential 
choice could be the so-called remaining phosphorus (Prem) (Bache \& Williams, 1971), which is the $\mathrm{P}$ concentration that remains in solution after shaking $2.5 \mathrm{~g}$ of soil with $25 \mathrm{~mL}$ of $0.01 \mathrm{CaCl}_{2} \mathrm{~mol} \mathrm{~L}^{-1}$ containing $60 \mathrm{mg} \mathrm{L}^{-1} \mathrm{P}$ for $1 \mathrm{~h}$ (Alvarez V. et al., 2000). Experimental observations indicated that nonallophanic kaolinitic soils usually have high Prem values, which decrease when the soil becomes richer in gibbsite and iron oxides. In general, minerals such as gibbsite and goethite are more abundant in highly weathered soils; since these minerals have surface $\mathrm{OH}$ groups that can be protonated and high values of point zero charge (PZC), the number of positive surface charges tends to be higher in gibbsite- and goethiterich soils even at moderate acidity. It can therefore be concluded that soils with low Prem values can adsorb greater amounts of anions through both innerand outer-sphere complexations. The advantage of using Prem as anion-adsorption index can be ascribed to its simpler and faster determination and to its greater dependence on soil mineralogy than on soil texture (Alves \& Lavorenti, 2004).

Considering that: ( $i$ ) the minerals gibbsite, hematite, and goethite are the main anion adsorbents in non-allophanic tropical soils and that their contents increase as these soils weather; (ii) both the point of zero charge (PZC) and soil $\mathrm{pH}$ values influence the sign and amount of electrical charges in the soil mineral surfaces; and (iii) that the higher amounts of negative surface charges and of anions such as carbonate, phosphate and sulfate usually found in the soil suface $(0-20 \mathrm{~cm})$ disfavor nitrate adsorption, it can be assumed that acidic subsoils with greater oxide amounts and, for this reason, low Prem values, are able to adsorb more $\mathrm{NO}_{3}{ }^{-}$than acidic subsoils richer in kaolinite. In this context, the purpose of this study was to evaluate the potential of Prem together with soil $\mathrm{pH}$ values measured in water $\left(\mathrm{pH} \mathrm{H}_{2} \mathrm{O}\right)$ and in 1 mol L-1 $\mathrm{KCl}(\mathrm{pH} \mathrm{KCl})$ for predictions related to the delay of $\mathrm{NO}_{3}^{-}$leaching from subsurface layers of Ferralsols and Acrisols.

\section{MATERIAL AND METHODS}

\section{Soils}

Twenty four samples were taken from the subsoil (20-40 cm) of Ferralsols and Acrisols at different locations in São Paulo State, air-dried, ground and passed through a $2-\mathrm{mm}$ sieve. The soil contents of oxidizable carbon and clay-size particles were evaluated using the the Walkley-Black and the pipette method, respectively, whereas the soil particle density was determined through the pycnometer procedure (Embrapa, 1997). (Embrapa, 1997). The $\mathrm{Si}, \mathrm{Fe}$ and $\mathrm{Al}$ contents associated to secondary minerals were determined after boiling the soil samples in $9 \mathrm{~mol} \mathrm{~L}^{-1}$ $\mathrm{H}_{2} \mathrm{SO}_{4}$ at a solid/solution ratio of 1:20 (Embrapa, 1997); from the results, the weathering indices $\mathrm{Ki}\left(\mathrm{SiO}_{2}\right.$ $\left.\mathrm{Al}_{2} \mathrm{O}_{3}, \mathrm{~mol} \mathrm{~mol}^{-1}\right)$ and $\mathrm{Kr}\left[\mathrm{SiO}_{2} /\left(\mathrm{Al}_{2} \mathrm{O}_{3}+\mathrm{Fe}_{2} \mathrm{O}_{3}\right)\right.$, mol $\mathrm{mol}^{-1}$ ] were calculated. Oxalate-extractable $\mathrm{Fe}$ and $\mathrm{Al}$ $\left(\mathrm{Fe}_{\mathrm{o}}\right.$ and $\left.\mathrm{Al}_{0}\right)$ contents were also determined according to Buurman et al. (1996).

The soil $\mathrm{pH}$ values were measured in water $\mathrm{pH}$ $\left.\mathrm{H}_{2} \mathrm{O}\right), 0.01 \mathrm{~mol} \mathrm{~L}^{-1} \mathrm{CaCl}_{2}(\mathrm{pH} \mathrm{CaCl})$ and $1 \mathrm{~mol} \mathrm{~L}^{-1}$ $\mathrm{KCl}(\mathrm{pH} \mathrm{KCl})$ at a solid/liquid ratio of 1:2.5 (Embrapa, 1997). Remaining phosphorus (Prem) was determined as proposed by Alvarez V. et al. (2000), by shaking $2.5 \mathrm{~g}$ of soil with $25 \mathrm{~mL}$ of $0.01 \mathrm{~mol} \mathrm{~L}^{-1} \mathrm{CaCl}_{2}$, containing $60 \mathrm{mg} \mathrm{L}^{-1} \mathrm{P}$ for $1 \mathrm{~h}$, and analyzing the filtered solutions for $\mathrm{P}$ by the blue molybdenum method of Murphy \& Riley (1962).

The cation and anion exchange capacities (CEC and AEC) were determined by saturating the soils with the ions $\mathrm{Ca}^{2+}$ and $\mathrm{Cl}^{-}$through successive shakings and centrifugations of $2 \mathrm{~g}$ of soil with $20 \mathrm{~mL}$ of unbuffered $0.01 \mathrm{~mol} \mathrm{~L}^{-1} \mathrm{CaCl}_{2}$ in 50 - $\mathrm{mL}$ centrifuge tubes. When the $\mathrm{Ca}^{2+}$ and $\mathrm{Cl}^{-}$concentrations in the supernatants reached $0.02 \mathrm{~mol}_{\mathrm{c}} \mathrm{L}^{-1}$, the ions were desorbed in two extractions with $15 \mathrm{~mL}$ of $0.5 \mathrm{~mol} \mathrm{~L}^{-1}$ $\mathrm{MgSO}_{4}$. Both extracts were combined in flasks filled to the $50-\mathrm{mL}$ mark with the extractant and analyzed for $\mathrm{Ca}^{2+}$ by atomic absorption spectrophotometry and for $\mathrm{Cl}^{-}$by colorimetry (Florence \& Farrar, 1971). The soil CEC and AEC values were calculated, respectively, from the respective amounts of $\mathrm{Ca}^{2+}$ and $\mathrm{Cl}^{-}$ determined after subtraction of the contributions of these ions in the entrapped solutions; whose volumes were calculated as the difference between the masses of the tubes containing the soils weighed before the first application of the saturated solution and after the last centrifugation and discarding of the supernatant.

\section{Nitrate adsorption and leaching}

To assess $\mathrm{NO}_{3}$ - adsorption, $2.5 \mathrm{~g}$ of air-dried and sieved $(\phi \leq 2 \mathrm{~mm})$ soil and $25 \mathrm{~mL}$ of $1 \mathrm{~mol} \mathrm{~L}^{-1} \mathrm{KCl}$ were transferred to $50-\mathrm{mL}$ centrifuge tubes that were shaken for $2 \mathrm{~h}$ and centrifuged. The supernatants were analyzed for $\mathrm{NO}_{3}{ }^{-}$according to Yang et al. (1998). The same procedure was repeated using water as extractant. The adsorbed nitrate was considered equal to the difference between the $\mathrm{KCl}$ - and $\mathrm{H}_{2} \mathrm{O}$-extractable $\mathrm{NO}_{3}{ }^{-}$soil contents (Ryan et al., 2001).

Leaching experiments were carried out in preweighed PVC tubes (internal diameter $5 \mathrm{~cm}$ ) with a fine stainless steel screen, lined with geotextile (bidim ${ }^{\circledR}$ ) attached to the bottom. After being packed with $20 \mathrm{~cm}$ of air-dried sieved $(\phi \leq 2 \mathrm{~mm})$ soil and "weighed, each PVC tube was vertically immersed from its bottom in 13,5 cm of deionized (DI) water for $24 \mathrm{~h}$;" afterwards, the column was hold in a support and DI water was dripped for more $24 \mathrm{~h}$ to give rise to a 1-cm liquid layer on the soil surface, which was kept with a lateral drain. When the flow became constant in the soil column, the water was replaced by an aqueous dripping solution containing $50 \mathrm{mg} \mathrm{L}^{-1}$ 
$\mathrm{KNO}_{3}$ and 25-mL effluent fractions were collected in the column bottom until their nitrate concentrations become equal to $50 \mathrm{mg} \mathrm{L}{ }^{-1}$. The $\mathrm{C} \mathrm{C}_{0}$ ratios, calculated from the nitrate concentrations of the effluent $(C)$ and influent solutions $\left(\mathrm{C}_{0}, 50 \mathrm{mg} \mathrm{L}^{-1}\right)$ were submitted with their respective cumulative numbers of pore volume to the software Disp (Borges Jr. \& Ferreira, 2006) for the calculation of the nitrate retardation factor from the numerical solution of the onedimensional convective-dispersive ion transport equation proposed by van Genuchten \& Wierenga (1986):

$$
R \frac{\partial \mathrm{C}_{\mathrm{r}}}{\partial t}=D \frac{\partial^{2} \mathrm{C}_{\mathrm{r}}}{\partial x^{2}}-v \frac{\partial \mathrm{C}_{\mathrm{r}}}{\partial x}
$$

where $R$ is the retardation factor, $\mathrm{C}_{\mathrm{r}}$ is the ion concentration in the soil solution $\left(\mathrm{mg} \mathrm{L}^{-1}\right), \mathrm{t}$ is the time (min), $D$ is the dispersive-diffusive coefficient $\left(\mathrm{m}^{2}\right.$ $\left.\min ^{-1}\right), \mathrm{x}$ is the distance from soil surface $(\mathrm{m})$, and $v$ is the flow velocity $\left(\mathrm{m} \mathrm{min}^{-1}\right)$.

The total volume occupied by pores in each soil column was calculated by multiplying the soil volume $\left(392.7 \mathrm{~cm}^{3}\right)$ by the soil porosity, which in turn was calculated as $1-\left(\rho_{b}-\rho_{p}\right)$, where $\rho_{b}$ is the soil bulk density calculated as the ratio of soil weight by the soil volume in the PVC tube, and $\rho_{p}$ is the soil particle density.

\section{Statistical analyses}

The experimental results were subjected to simple linear correlation and to multiple regression analyses using the Statistical Analysis System - SAS version 9.1 (SAS, 1994).

\section{RESULTS AND DISCUSSION}

\section{Soil characterization}

The classification, localization and the evaluated properties of the studied subsoils (Table 1), show that most of them were clayey (clay $>350 \mathrm{~g} \mathrm{~kg}^{-1}$ ) and acidic (pH CaCl 2 < 5.5) (Embrapa, 2006). The sample from Adamantina (soil 24) was the least weathered $(\mathrm{Ki}=3.9 ; \mathrm{Kr}=3.2)$ whereas the sample from Jardinópolis (soil 1) was the most weathered one $(\mathrm{Ki}=0.1 ; \mathrm{Kr}=0)$; these conclusions were based on the fact that the $9 \mathrm{~mol} \mathrm{~L}^{-1} \mathrm{H}_{2} \mathrm{SO}_{4}$ digestion dissolves all soil minerals but quartz. Therefore, the richer in oxides such as gibbsite, hematite, and goethite the soil is, the lesser will be its $\mathrm{Ki}$ and $\mathrm{Kr}$ values; on the other hand, for soils richer in minerals such as vermiculite, illite, and kaolinite the greater $\mathrm{Si}$ contents determined after the sulfuric digestion give rise to higher $\mathrm{Ki}$ and $\mathrm{Kr}$ values (Embrapa, 2006). Considering the $\mathrm{Kr}$ values as an approximate criterion to discriminate kaolinitic $(\mathrm{Kr}>0.75)$ from oxidic $(\mathrm{Kr}<0.75)$ tropical soils (Embrapa, 2006), it can be inferred that kaolinite was the most abundant mineral in the clay and silt fractions in 16 of the 24 subsoils. The $\mathrm{Fe}$ and $\mathrm{Al}$ contents extracted with the ammonium oxalate solution ranged from 0 (soil 24) to $8 \mathrm{~g} \mathrm{~kg}^{-1}$ (soil 2) for Fe and from 1 (soils 13, 20, 21, 22, 23 , and 24) to $7 \mathrm{~g} \mathrm{~kg}^{-1}$ (soil 2) for $\mathrm{Al}$. The Prem values varied from 0 (soils 3 and 7) to $54.3 \mathrm{mg} \mathrm{L}^{-1}$ (soil 21) with a mean value of $19.9 \mathrm{mg} \mathrm{L}^{-1}$ and were inversely correlated with the soil contents of $\mathrm{Fe}-\mathrm{H}_{2} \mathrm{SO}_{4}(r=$ $\left.0.70^{* *}\right), \mathrm{Al}-\mathrm{H}_{2} \mathrm{SO}_{4}\left(r=-0.93^{* *}\right), \mathrm{Fe}_{0}\left(r=-0.56^{* *}\right)$, and $\mathrm{Al}_{0}\left(r=-0.88^{* *}\right)$, and positively correlated with the weathering indexes $\mathrm{Ki}\left(r=0.71^{* *}\right)$ and $\mathrm{Kr}\left(r=0.66^{* *}\right)$. These correlations indicate that Prem can be a suitable estimator of the soil content of $\mathrm{Fe}$ and $\mathrm{Al}$ oxides. An example of the dependence of Prem on the soil mineralogy can be observed in the soils 1 and 9, which had equal contents of clay-size particles $\left(381 \mathrm{~g} \mathrm{~kg}^{-1}\right)$ but quite different Prem values (2.4 and $18.1 \mathrm{mg} \mathrm{L}^{-1}$, the lower value in the more oxidic soil). Furthermore, the coefficient of variation of the Prem values among the studied samples was high (84\%); this indicates a great capacity of discriminating the subsoils according to the $\mathrm{Fe}$ and $\mathrm{Al}$ oxide contents.

The oxidizable carbon $(\mathrm{OC})$ contents in the subsoils ranged from $2.3 \mathrm{~g} \mathrm{~kg}^{-1}$ for the Haplic Acrisol of Votuporanga (soil 21) to $24.4 \mathrm{~g} \mathrm{~kg}^{-1}$ for the Rhodic Ferralsol of Miguelópolis (soil 2), with a mean value of $10.6 \mathrm{~g} \mathrm{~kg}^{-1}$. No correlation was observed between the $\mathrm{OC}$ contents and the values of cation and the anion exchange capacities (CEC and AEC). On the other hand, the CEC values were directly correlated with the soil $\mathrm{pH}$ measured in water $\left(r=0.55^{* *}\right)$ and in $0.01 \mathrm{~mol} \mathrm{~L}^{-1} \mathrm{CaCl}_{2}\left(r=0.47^{*}\right)$.

The subsoil AEC ranged from 0.13 (soil 5) to 1.05 $\mathrm{cmol}_{\mathrm{c}} \mathrm{kg}^{-1}$ (soil 3), with a mean value of $0.35 \mathrm{cmol}_{\mathrm{c}} \mathrm{kg}^{-1}$, and was correlated with Prem $\left(r=-0.63^{* *}\right)$ and with the contents of clay $\left.\left(r=0.49^{* *}\right), \mathrm{Fe}-\mathrm{H}_{2} \mathrm{SO}_{4} r=0.44^{* *}\right)$, $\mathrm{Al}-\mathrm{H}_{2} \mathrm{SO}_{4}\left(r=0.63^{* *}\right)$ and $\mathrm{Al}_{0}\left(r=0.42^{* *}\right)$. No correlation was observed between AEC and the soil $\mathrm{pH}$ measured in water, $0.01 \mathrm{~mol} \mathrm{~L}^{-1} \mathrm{CaCl}_{2}$ or $1 \mathrm{~mol} \mathrm{~L}^{-1} \mathrm{KCl}$.

The multiple regression of AEC with Prem, $\mathrm{pH}$ $\mathrm{KCl}$ and $\mathrm{pH} \mathrm{H}_{2} \mathrm{O}$ (Table 2) showed that these variables explained $52 \%$ of the AEC variation among the studied soils. According to Neter et al. (1990), when the predictor variables of a multiple regression model are correlated to each other, multi-collinearity is said to exist. In this case, the following problems can occur: (i) parameter estimates may not be significant, despite the existence of a definite statistical relationship, and (ii) a parameter estimate may have a sign different from the expected. Multi-collinearity can be detected by calculating the variance inflation factors (VIF), which measure the inflation of the variances for the regression coefficients above the expected if there is no correlation among the predictor variables; a VIF value $>10$ indicates the presence of strong multicollinearity. The calculated VIF values (Table 2) indicated absence of multi-collinearity among the predictor variables, so that the signs of their 
Table 1. Classification, localization and selected properties of the studied soils

\begin{tabular}{|c|c|c|c|c|c|c|c|c|c|c|c|c|c|c|c|c|c|}
\hline \multirow[t]{3}{*}{ Soil } & \multirow[t]{2}{*}{ Classification $^{(1)}$} & \multirow[t]{2}{*}{ Localization } & \multirow[t]{2}{*}{$\mathbf{C}^{(2)}$} & \multirow[t]{2}{*}{ Clay $^{(3)}$} & \multirow[t]{2}{*}{$\mathrm{SiO}_{2}^{(4)}$} & \multirow{2}{*}{\multicolumn{2}{|c|}{$\mathrm{Fe}_{2} \mathrm{O}_{3}{ }^{(4)} \mathrm{Al}_{2} \mathrm{O}_{3}{ }^{(4)}$}} & \multirow[t]{3}{*}{$\mathbf{K} \mathbf{i}^{(5)}$} & \multirow[t]{3}{*}{$\mathbf{K} \mathbf{r}^{(5)}$} & \multirow{2}{*}{\multicolumn{3}{|c|}{$\mathrm{Fe}_{\mathrm{o}}{ }^{(6)} \mathrm{Al}_{\mathrm{o}}{ }^{(6)} \mathrm{Prem}^{(7)}$}} & \multicolumn{3}{|c|}{$\mathbf{p H}^{(8)}$} & \multicolumn{2}{|c|}{$\mathrm{CEC}^{(9)} \mathrm{AEC}^{(9)}$} \\
\hline & & & & & & & & & & & & & $\mathrm{CaCl}_{2}$ & $\mathrm{KCl}$ & $\mathrm{H}_{2} \mathrm{O}$ & & \\
\hline & & & & & $\mathrm{g} \mathrm{kg}^{-1}$ & & & & & $-\mathrm{g}$ & $g^{-1}$ & $\mathrm{mg} \mathrm{L}^{-1}$ & & & & $-\mathrm{cmol}$ & ${ }_{\mathrm{c}} \mathrm{kg}^{-1}$ \\
\hline 1 & Xanthic Ferralsol & Jardinópolis & 15.1 & 381 & 8 & 300 & 276 & 0.1 & 0.0 & 3 & 6 & 2.4 & 4.6 & 4.9 & 5.0 & 0.65 & 0.66 \\
\hline 2 & Rhodic Ferralsol & Miguelópolis & 24.4 & 407 & 93 & 246 & 288 & 0.5 & 0.4 & 8 & 7 & 9.7 & 4.7 & 4.5 & 5.3 & 2.64 & 0.22 \\
\hline 3 & Xanthic Ferralsol & Guaíra & 6.2 & 438 & 126 & 189 & 292 & 0.7 & 0.5 & 3 & 5 & 0.0 & 5.9 & 6.2 & 5.7 & 1.46 & 1.05 \\
\hline 4 & Xanthic Ferralsol & São Pedro & 22.1 & 350 & 68 & 64 & 148 & 0.8 & 0.6 & 2 & 5 & 20.0 & 4.4 & 4.2 & 6.2 & 1.88 & 0.23 \\
\hline 5 & Rhodic Ferralsol & Ribeirão Preto & 9.3 & 397 & 89 & 139 & 150 & 1.0 & 0.6 & 3 & 3 & 20.3 & 7.3 & 7.4 & 7.8 & 6.13 & 0.13 \\
\hline 6 & Xanthic Ferralsol & Itirapina & 6.6 & 319 & 68 & 39 & 153 & 0.8 & 0.7 & 1 & 2 & 29.3 & 4.7 & 4.6 & 5.4 & 0.97 & 0.19 \\
\hline 7 & Xanthic Ferralsol & $\begin{array}{l}\text { Espírito Santo } \\
\text { do Pinhal }\end{array}$ & 6.6 & 559 & 147 & 96 & 309 & 0.8 & 0.7 & 1 & 4 & 0.0 & 5.4 & 5.9 & 5.0 & 0.56 & 1.04 \\
\hline 8 & Rhodic Ferralsol & Cordeirópolis & 12.8 & 549 & 160 & 189 & 254 & 1.1 & 0.7 & 3 & 5 & 3.6 & 4.6 & 4.5 & 5.1 & 1.55 & 0.58 \\
\hline 9 & Rhodic Ferralsol & Guaíra & 16.7 & 381 & 105 & 107 & 170 & 1.1 & 0.8 & 4 & 4 & 18.1 & 3.9 & 3.9 & 4.6 & 1.31 & 0.43 \\
\hline 10 & Rhodic Ferralsol & Leme & 10.5 & 491 & 169 & 193 & 259 & 1.1 & 0.8 & 3 & 3 & 5.0 & 5.3 & 5.2 & 5.9 & 2.04 & 0.35 \\
\hline 11 & Rhodic Ferralsol & Luis Antônio & 10.9 & 442 & 177 & 261 & 220 & 1.4 & 0.8 & 4 & 4 & 8.1 & 4.0 & 4.0 & 4.5 & 2.14 & 0.41 \\
\hline 12 & Xanthic Ferralsol & Piracicaba & 3.9 & 299 & 89 & 43 & 141 & 1.1 & 0.9 & 2 & 4 & 16.9 & 3.9 & 4.0 & 4.3 & 1.65 & 0.19 \\
\hline 13 & Haplic Acrisol & Vera Cruz & 4.3 & 208 & 64 & 21 & 93 & 1.2 & 1.0 & 1 & 1 & 35.9 & 4.1 & 4.1 & 4.4 & 0.75 & 0.20 \\
\hline 14 & Haplic Acrisol & Capão Bonito & 7.8 & 365 & 135 & 54 & 175 & 1.3 & 1.1 & 2 & 3 & 19.2 & 4.4 & 4.2 & 6.4 & 2.70 & 0.24 \\
\hline 15 & Haplic Acrisol & $\begin{array}{l}\text { Monte Alegre } \\
\text { do Sul }\end{array}$ & 19.0 & 489 & 177 & 82 & 216 & 1.4 & 1.1 & 3 & 5 & 11.0 & 4.5 & 4.3 & 5.1 & 4.15 & 0.23 \\
\hline 16 & Haplic Acrisol & Mococa & 9.7 & 462 & 194 & 104 & 226 & 1.5 & 1.1 & 2 & 3 & 22.8 & 5.4 & 5.2 & 5.9 & 2.28 & 0.23 \\
\hline 17 & Haplic Acrisol & Itapetininga & 12.0 & 575 & 186 & 54 & 242 & 1.3 & 1.2 & 1 & 5 & 2.3 & 4.2 & 4.0 & 4.9 & 3.32 & 0.48 \\
\hline 18 & Haplic Acrisol & Mococa & 12.0 & 442 & 203 & 104 & 234 & 1.5 & 1.2 & 2 & 3 & 21.9 & 5.8 & 5.6 & 6.3 & 5.18 & 0.21 \\
\hline 19 & Rhodic Ferralsol & Tatuí & 14.4 & 628 & 269 & 175 & 284 & 1.6 & 1.2 & 5 & 6 & 2.8 & 4.1 & 4.0 & 4.6 & 2.95 & 0.41 \\
\hline 20 & Haplic Acrisol & $\begin{array}{l}\text { Monte Alegre } \\
\text { do Sul }\end{array}$ & 11.6 & 262 & 130 & 64 & 133 & 1.7 & 1.3 & 2 & 1 & 35.6 & 5.0 & 4.8 & 5.5 & 3.47 & 0.24 \\
\hline 21 & Haplic Acrisol & Votuporanga & 2.3 & 101 & 36 & 25 & 25 & 2.5 & 1.5 & 1 & 1 & 54.3 & 5.5 & 5.3 & 4.6 & 1.66 & 0.19 \\
\hline 22 & Haplic Acrisol & Andradina & 5.0 & 149 & 60 & 32 & 42 & 2.4 & 1.7 & 1 & 1 & 52.8 & 5.6 & 5.4 & 6.2 & 2.05 & 0.22 \\
\hline 23 & Haplic Acrisol & Adamantina & 6.2 & 150 & 77 & 32 & 48 & 2.7 & 1.9 & 1 & 1 & 39.1 & 5.2 & 4.9 & 5.4 & 1.98 & 0.18 \\
\hline 24 & Haplic Acrisol & Adamantina & 3.9 & 94 & 40 & 7 & 17 & 3.9 & 3.2 & 0 & 1 & 45.3 & 4.2 & 3.9 & 6.0 & 1.18 & 0.20 \\
\hline
\end{tabular}

(1) FAO (2006). ${ }^{(2)}$ Oxidizable carbon (Embrapa, 1997). ${ }^{(3)}$ Pipette method (Embrapa, 1997). ${ }^{(4)}$ Soil contents of $\mathrm{Si}, \mathrm{Al}$ and $\mathrm{Fe}$ extracted by boiling $9 \mathrm{~mol} \mathrm{~L}^{-1} \mathrm{H}_{2} \mathrm{SO}_{4}$ expressed as their respective oxides (Embrapa, 1997). ${ }^{(5)}$ Weathering indexes given by $\mathrm{Ki}=1.7 \mathrm{SiO}{ }_{2} /$ $\mathrm{Al}_{2} \mathrm{O}_{3}$ and $\mathrm{Kr}=1.7 \mathrm{SiO}_{2} /\left(0.63 \mathrm{Fe}_{2} \mathrm{O}_{3}+\mathrm{Al}_{2} \mathrm{O}_{3}\right) .{ }^{(6)}$ Soil contents of oxalate-extractable $\mathrm{Fe}$ and Al. ${ }^{(7)}$ Remaining phosphorus (Alvarez V. et al., 2000). ${ }^{(8)} \mathrm{pH}$ measured in $0.01 \mathrm{~mol} \mathrm{~L}^{-1} \mathrm{CaCl}_{2}(\mathrm{pH} \mathrm{CaCl})_{2}$, water $\left(\mathrm{pH} \mathrm{H}_{2} \mathrm{O}\right)$, and $1 \mathrm{~mol} \mathrm{~L}^{-1} \mathrm{KCl}(\mathrm{pH} \mathrm{KCl})(\mathrm{Embrapa}, 1997)$.

${ }^{(9)}$ Cation exchange capacity and anion exchange capacity.

Table 2. Results of the multiple regression analysis relating the anion exchange capacity (AEC) to remaining phosphorus (Prem), soil pH measured in water $\left(\mathrm{pH} \mathrm{H}_{2} \mathrm{O}\right)$, and soil $\mathrm{pH}$ measured in $1 \mathrm{~mol} \mathrm{~L}^{-1} \mathrm{KCl}(\mathrm{pH} \mathrm{KCl})$

\begin{tabular}{cccccc}
\hline Parameter & Estimate & $\begin{array}{c}\text { Standard } \\
\text { error }\end{array}$ & $\boldsymbol{t}$ value & prob>t & VIF $^{(\mathbf{1})}$ \\
\hline$a_{0}$ & 0.57062 & 0.25264 & 2.26 & 0.0352 & 0.00 \\
$a_{1}$ & -0.00850 & 0.00223 & -3.82 & 0.0011 & 1.04 \\
$a_{2}$ & -0.14204 & 0.05744 & -2.47 & 0.0225 & 1.67 \\
$a_{3}$ & 0.15083 & 0.05353 & 2.82 & 0.0106 & 1.63 \\
\hline
\end{tabular}

$\mathrm{AEC}=a_{0}+a_{1}$ Prem $+a_{2} \mathrm{pH} \mathrm{H} \mathrm{H}_{2} \mathrm{O}+a_{3} \mathrm{pH} \mathrm{KCl} ; F$-value $=9.32 ;$ prob $>F=0.0005 ; \mathrm{R}^{2}=0.52 ; n=24$. (1) VIF: variance inflation factor. coefficients are in real agreement with their expected individual effects on AEC. The negative signs of Prem and $\mathrm{pH} \mathrm{H}_{2} \mathrm{O}$ show that the AEC increases as both decrease, i.e., the AEC increases as the soil becomes oxide-richer (low Prem) and more acidic (low $\mathrm{pH} \mathrm{H}_{2} \mathrm{O}$ ) since both situations increase the number of protonated hydroxyl surface groups $\left(-\mathrm{OH}+\mathrm{H}^{+} \rightarrow \mathrm{OH}_{2}^{+}\right)$; furthermore, the AEC increases as the soil $\mathrm{pH} \mathrm{KCl}$ values become higher, which can be ascribed to the positive correlation observed between the point of zero charge and the $\mathrm{pH} \mathrm{KCl}$ values of Ferralsols and Acrisols with low contents of exchangeable $\mathrm{Al}$ and organic matter (Alves \& Lavorenti, 2005). Therefore, despite the low value calculated for the determination coefficient $\left(\mathrm{R}^{2}\right)$ of the regression model, which could be improved by increasing the experimental dataset used for the fitting (Cagliari et al., 2011), the obtained 
equation was able to indicate the expected individual effects of the predictor variables on AEC. This model allows estimations, for instance, of different AEC values for soils with different mineralogies and similar $\mathrm{pH} \mathrm{H}_{2} \mathrm{O}$ values or for soils with different mineralogies and similar clay contents.

\section{Nitrate adsorption and leaching}

The subsoil content of adsorbed $\mathrm{NO}_{3}{ }^{-}$ranged from 0 (soil 11) to $58.7 \mathrm{mg} \mathrm{kg}^{-1}$ (soil 7) with a mean value of $10.2 \mathrm{mg} \mathrm{kg}^{-1}$ (Table 3 ) and was not correlated with the soil clay content, $\mathrm{pH} \mathrm{KCl}$, and $\mathrm{pH} \mathrm{H}_{2} \mathrm{O}$. On the other hand, it was inversely correlated with Prem $\left(r=-0.42^{*}\right)$ and directly correlated with AEC $\left(r=0.71^{* *}\right)$. The multiple regression of adsorbed $\mathrm{NO}_{3}{ }^{-}$against Prem, $\mathrm{pH} \mathrm{H}_{2} \mathrm{O}$, and $\mathrm{pH} \mathrm{KCl}$ was not statistically significant ( $F$-value $=2.07, p>F=0.1371)$.

The nitrate breakthrough curves for the studied soils were between those drawn for the Haplic Acrisol of Monte Alegre do Sul (soil 20) and for Xanthic Ferrasol from Guaíra (soil 3) (Figure 1), which had, respectively, the least and the highest nitrate retardation factors $\left(\mathrm{RNO}_{3}{ }^{-}\right)$(Table 3$)$. The mean $\mathrm{RNO}_{3}{ }^{-}$ value (0.93) indicated weak $\mathrm{NO}_{3}$ - retention by the subsoil samples and was about 15 times lower than the value obtained in similar breakthrough experiments for phosphate in Brazilian Ferralsols (Oliveira et al., 2004). This agrees with the weaker outer-sphere and the stronger inner-sphere surface complexations responsible for the respective retentions of $\mathrm{NO}_{3}$ - and phosphate in variable charge soils (Ji, 1997; Zhang \& Yu, 1997). The anion exchange capacity was the only evaluated soil property that correlated with the $\mathrm{NO}_{3}{ }^{-}$retardation factor $\left(r=0.70^{* *}\right)$, in close agreement with the electrostatic nature of $\mathrm{NO}_{3}{ }^{-}$ adsorption.

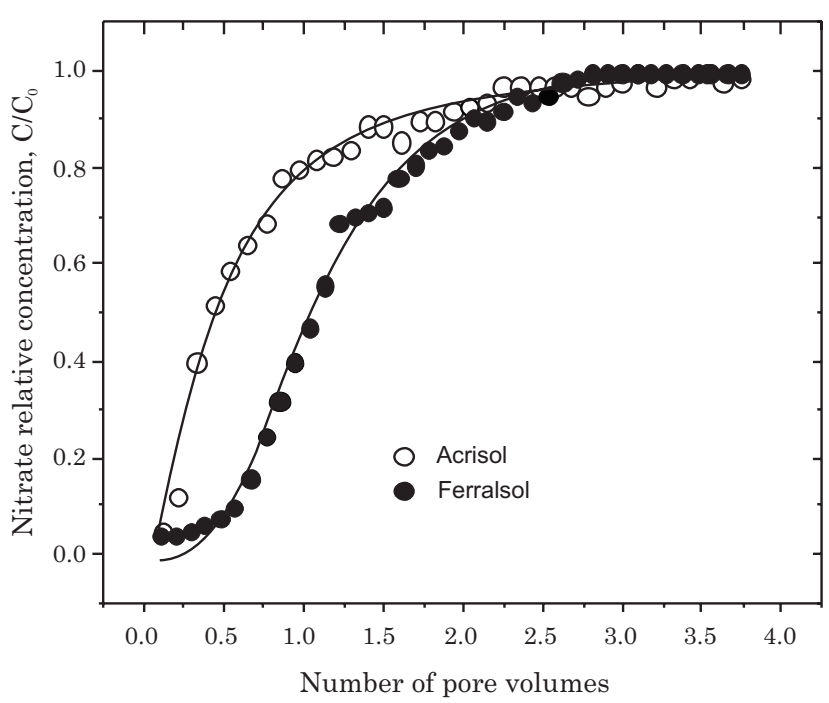

Figure 1. Nitrate breakthrough curves of Acrisol samples from Monte Alegre do Sul (soil 20) and Ferralsol from Guaíra (soil 3).
Table 3. Soil contents and retardation factors of nitrate in the studied soils

\begin{tabular}{|c|c|c|c|c|}
\hline \multirow[t]{2}{*}{ Soil } & \multicolumn{3}{|c|}{ Nitrate } & \multirow[t]{2}{*}{$\mathrm{RNO}_{3}{ }^{-(4)}$} \\
\hline & $\mathrm{KCl}^{(1)}$ & $\mathrm{H}_{2} \mathrm{O}^{(2)}$ & Adsorbed $^{(3)}$ & \\
\hline & & $\mathrm{mg} \mathrm{kg}^{-1}$ & & \\
\hline 1 & 62.1 & 53.6 & 8.5 & 1.02 \\
\hline 2 & 63.0 & 38.8 & 24.2 & 0.84 \\
\hline 3 & 148.6 & 117.0 & 31.6 & 1.19 \\
\hline 4 & 39.7 & 26.3 & 13.4 & 0.94 \\
\hline 5 & 97.0 & 96.4 & 0.6 & 0.76 \\
\hline 6 & 13.9 & 9.1 & 4.8 & 0.79 \\
\hline 7 & 185.9 & 127.2 & 58.7 & 1.15 \\
\hline 8 & 26.4 & 14.3 & 12.1 & 1.13 \\
\hline 9 & 24.7 & 24.0 & 0.8 & 0.94 \\
\hline 10 & 28.1 & 26.3 & 1.8 & 0.96 \\
\hline 11 & 19.0 & 19.0 & 0.0 & 1.15 \\
\hline 12 & 31.4 & 29.7 & 1.7 & 0.98 \\
\hline 13 & 55.5 & 55.3 & 0.1 & 0.97 \\
\hline 14 & 34.7 & 13.7 & 21.0 & 0.92 \\
\hline 15 & 34.7 & 25.1 & 9.6 & 0.77 \\
\hline 16 & 33.9 & 30.2 & 3.6 & 0.73 \\
\hline 17 & 31.4 & 10.9 & 20.5 & 0.92 \\
\hline 18 & 82.9 & 81.6 & 1.3 & 0.85 \\
\hline 19 & 30.6 & 29.7 & 0.9 & 0.94 \\
\hline 20 & 35.5 & 25.1 & 10.4 & 0.70 \\
\hline 21 & 59.6 & 57.6 & 2.0 & 1.02 \\
\hline 22 & 27.2 & 22.3 & 5.0 & 0.90 \\
\hline 23 & 27.2 & 18.8 & 8.4 & 0.91 \\
\hline 24 & 38.0 & 33.1 & 4.9 & 0.95 \\
\hline
\end{tabular}

(1) Soil content of 1-mol L-1 KCl-extractable nitrate. ${ }^{(2)}$ Soil content of water-extractable nitrate. ${ }^{(3)}$ Soil content of adsorbed nitrate $\left[\mathrm{NO}_{3}{ }^{-}\right.$adsorved $=\mathrm{NO}_{3}^{-} \mathrm{KCl}-\mathrm{NO}_{3}-\mathrm{H}_{2} \mathrm{O}$ (Ryan et al., 2001)]. ${ }^{(4)}$ Nitrate retardation factor

For the soils $2,5,6,15,16,18$, and 20 , the $\mathrm{RNO}_{3}$ values ranged from 0.70 to 0.85 . It is probable that in these soils the $\mathrm{NO}_{3}$ - ions were electrostatically repelled rather than attracted, which characterizes the socalled negative adsorption (Ji, 1997). The negative correlation $\left(r=-0.68^{* *}\right)$ observed between $\mathrm{RNO}_{3}{ }^{-}$and the relative amount of negative surface charges, given by the ratio $[\mathrm{CEC} /(\mathrm{CEC}+\mathrm{AEC})] \mathrm{x} 100$, indicates that $\mathrm{RNO}_{3}-$ values tend to be low in soils where CEC is much higher than AEC. The $\mathrm{RNO}_{3}^{-}$values lower than 0.85 were observed in those samples presenting $[\mathrm{CEC} /(\mathrm{CEC}+\mathrm{AEC})] \times 100>90 \%$, indicating that these subsoils are highly susceptible to $\mathrm{NO}_{3}{ }^{-}$leaching under extreme rainfall conditions.

Finally, subsoils values of Prem, $\mathrm{pH} \mathrm{KCl}$, and $\mathrm{pH}$ $\mathrm{H}_{2} \mathrm{O}$ seem to be promising for the determination of appropriate amounts of nitric fertilizers for Ferralsols and Acrisols in order to minimize nitrate leaching. 
The adequate use of those properties for the above purpose should be further studied considering other aspects that also affect the $\mathrm{NO}_{3}{ }^{-}$behavior in cultivated soils. Among them, it can be pointed out the changes in crop $\mathrm{N}$ demand according to the growth stage and gypsum application which, in turn, allows for deeper root growth in acidic subsoils.

\section{CONCLUSIONS}

1. The multiple regression model based on the subsoil properties Prem, $\mathrm{pH} \mathrm{KCl}$, and $\mathrm{pH} \mathrm{H}_{2} \mathrm{O}$ allows a reliable estimation of AEC values in the subsurface (20-40 cm) layer of Ferralsols and Acrisols.

2. Considering that AEC is the most important electrochemical soil property related to nitrate adsorption, the resistance of the subsurface layer (20$40 \mathrm{~cm}$ ) of Ferralsols and Acrisols to nitrate leaching under saturated-flow condition can be estimated based on the subsoil properties Prem, $\mathrm{pH} \mathrm{KCl}$, and $\mathrm{pH}_{2} \mathrm{O}$.

\section{ACKNOWLEDGEMENT}

The authors are grateful to the National Council for Scientific and Technological Development (CNPq) for the financial support.

\section{LITERATURE CITED}

ADDISCOTT, T.M. Is it nitrate that threatens life or the scare about nitrate? J. Sci. Food Agr., 86:2005-2009, 2006.

ADDISCOTT, T.M. \& BENJAMIN, N. Nitrate and human health. Soil Use Manage., 20:98-104, 2004.

ALCÂNTARA, M.A.K. \& CAMARGO, O.A. Manipulação de carga e movimento de nitrato em horizontes $\mathrm{B}$ de um Latossolo Vermelho. Pesq. Agropec. Bras., 45: 204-212, 2010.

ALVAREZ V, V.H.; NOVAIS, R.F.; DIAS, L.E. \& OLIVEIRA, J.A. Determinação e uso do fósforo remanescente. B. Inf. SBCS, 25: 24-32, 2000.

ALVES, M.E. \& LAVORENTI, A. Remaining phosphorus and sodium fluoride $\mathrm{pH}$ in soils with different clay contents and clay mineralogies. Pesq. Agropec. Bras., 39: 241-246, 2004.

ALVES, M.E. \& LAVORENTI, A. Point of zero salt effect: Relationships with clay mineralogy of representative soils of the São Paulo state, Brazil. Pedosphere, 15: 545-553, 2005.

BACHE, B.W. \& WILLIAMS, E.G. Phosphate sorption index for soils. J. Soil Sci., 22: 289-301, 1971.
BORGES Jr., J.F.C. \& FERREIRA, P.A. Equações e programa computacional para cálculo do transporte de solutos no solo. R. Bras. Eng. Agrí. Amb., 10:604-611, 2006.

BRASIL. Fundação Nacional de Saúde. Portaria no 1469 de 29 de dezembro de 2000. Brasília: Fundação Nacional de Saúde, 2001. 32p.

BUURMAN, P.; LAGEN, van B. \& VELTHORST, E. Manual for soil and water analysis. Leiden, Backhuys Publishers, 1996. $314 \mathrm{p}$.

CAGLIARI, J.; VERONEZ, M.R. \& ALVES, M.E. Remaining phosphorus estimated by pedotransfer function. R. Bras. Ci. Solo, 35:203-212, 2011.

DYNIA, J.F. \& CAMARGO, O.A. Retenção de nitrato num solo de carga variável influenciada por adubação fosfatada e calagem. Pesq. Agropec. Bras., 34: 141-144, 1999.

EMPRESA BRASILEIRA DE PESQUISA AGROPECUÁRIA . EMBRAPA. Manual de métodos de análises de solos. Rio de Janeiro, Embrapa Solos, 1997. 212p.

EMPRESA BRASILEIRA DE PESQUISA AGROPECUÁRIA EMBRAPA. Sistema brasileiro de classificação de solos. 2.ed. Rio de Janeiro, Embrapa Solos, 2006. 306p.

FLORENCE, T.M. \& FARRAR, Y.J. Spectrophotometric determination of chloride at parts-per-billion level by mercury(II) thiocyanate method. Anal. Chim. Acta, 54:373-377, 1971.

FOOD AND AGRICULTURE ORGANIZATION - FAO. World reference base for soil resources 2006: a framework for international classification, correlation and communication. Rome, FAO, 2006. 145p. (World Soil Resources Report, 103).

HARMAND, J.M.; ÁVILA, H.; OLIVER, R.; SAINT-ANDRÉ, L. \& DAMBRINE, E. The impact of kaolinite and oxihydroxides on nitrate adsorption in deep layers of a Costarican Acrisol under coffee cultivation. Geoderma, 158:216-224, 2010.

JI, G.L. Electrostatic adsorption of anions. In: YU, T.R., ed. Chemistry of variable charge soils. New York, Oxford University Press, 1997. p.112-139.

MURPHY, J. \& RILEY, J.P. A modified single solution method for determination of phosphate in natural waters. Anal. Chim. Acta, 26:31-36, 1962.

NETER, J.; WASSERMAN, W. \& KUTNER, M.H. Applied linear statistical models: regression, analysis of variance and experimental designs. Boston, Irwin, 1990. 1181p.

OLIVEIRA, E.M.M.; RUIZ, H.A.; FERREIRA, P.A.; ALVAREZ V., V.H. \& BORGES Jr., J.F.C. Fatores de retardamento e coeficientes de dispersão-difusão de fosfato, potássio e amônio em solos de Minas Gerais. R. Bras. Eng. Agrí. Amb., 8:196-203, 2004.

RESENDE, A.V. Agricultura e qualidade da água: contaminação da água por nitrato. Planaltina: Embrapa Cerrados, 2002. 29p. (Documentos, 57)

RYAN, M.C.; GRAHAM, G.R. \& RUDOLPH, D.L. Constrasting nitrate adsorption in Andisols of two coffee plantations in Costa Rica. J. Environ. Qual,. 30:1848-1852, 2001. 
SAS. SAS: principles of regression analysis - course notes. Cary, SAS Institute, 2004. 655p.

van GenuChten, M.T. \& WIEREnGA, P.J. Solute dispersion coefficients and retardation factors. In: KLUTE, A. ed. Methods of soil analysis: Part 1. Physical and mineralogical methods. Madison, ASA and SSSA, 1986. p.1025-1031.
YANG, J.E.; SKOGLEY, E.O.; SCHAFF, B.E. \& KIM, J.J. A simple spectrophotometric determination of nitrate in water, resin, and soil extracts. Soil Sci. Soc Am. J., 62:11081115, 1998.

ZHANG, G.Y. \& YU, T.R. Coordination adsorption of anions. In: YU, T.R., ed. Chemistry of variable charge soils. New York, Oxford University Press, 1997. p.175-218. 